\title{
Physico-Chemical and Thermal Characterization of a Lignocellulosic Fiber, Extracted from the Bast of Cola lepidota Stem
}

\author{
Ndoumou Belinga Rémy Legrand1, Meva'a Lucien², Ouagne Pierre³, Betene Ebanda Fabien', \\ Noah Pierre Marcel'1, Atangana Ateba Jean'1
}

${ }^{1}$ Laboratoire de Mécanique (LME), UFD SI, Université de Douala, Douala, Cameroun

${ }^{2}$ Laboratoire d'Ingénierie Civile et Mécanique, Université de Yaoundé I, Yaoundé, Cameroun

${ }^{3}$ Laboratoire Génie de Production (LGP), ENI de Tarbes, Tarbes, France

Email: nbr10490@gmail.com

How to cite this paper: Legrand, N.B.R., Lucien, M., Pierre, O., Fabien, B.E., Marcel, N.P. and Jean, A.A. (2020) Physico-Chemical and Thermal Characterization of a Lignocellulosic Fiber, Extracted from the Bast of Cola lepidota Stem. Journal of Minerals and Materials Characterization and Engineering, 8, 377-392. https://doi.org/10.4236/jmmce.2020.85024

Received: July 10, 2020

Accepted: August 16, 2020

Published: August 19, 2020

Copyright $\odot 2020$ by author(s) and Scientific Research Publishing Inc. This work is licensed under the Creative Commons Attribution International License (CC BY 4.0).

http://creativecommons.org/licenses/by/4.0/

\section{(c) (i) Open Access}

\begin{abstract}
In this research work, fiber extracted from the bark of Cola lepidota $(C L)$ plant, grown in the flora of Southern part of Cameroon, was investigated for composites reinforcement. The investigation was carried via evaluation of water absorption capacity, moisture content, real density, porosity, chemical composition, chemical structure and thermal behaviour. It was discovered that the new fiber has relatively low moisture content and water absorption capacity similar to those of other investigated natural fibers such as flax, sisal, coconut, hemp and jute. Its porosity was found appropriate for composite production and the fiber was found to be thermally stable up to $230^{\circ} \mathrm{C}$, with maximum degradation temperature of $325^{\circ} \mathrm{C}$. The main constituents of the fibre include cellulose, hemicellulose and lignin. In conclusion, based on the properties investigated, this fiber is considered suitable for composite manufacture.
\end{abstract}

\section{Keywords}

Cola lepidota Fiber, Thermal Stability, Physico-Chemical Characteristics, FTIR-ATR, Liber, Stem

\section{Introduction}

The valorization of plant biomass through the use of ligneous resources for the design and production of composite structures is a current issue in the research sector and applications in automotive, construction, goods and leisure industries are more and more observable. This visibility is demonstrated by the man- 
ufacturing of equipments such as: prostheses, tennis rackets, turbine blades, vehicle doors, shutters and roofs, etc. [1] [2]. Moreover, the use of products obtained from these materials is in line with the Kyoto Protocol's requirements for sustainable development and environmental protection [3]. Thus, the rush to substitute synthetic fibers with natural fibers in composite structures is justified.

Apart from their eco-friendly aspect, biofibers stand out for remarkable specific mechanical properties and relatively low cost [4]. However, their qualities depend on the quality of the fabrication [5]. The choice of the manufacturing process of an ecological composite requires the knowledge of some fundamental elements. Thermal behaviours such as the maximum degradation temperature and the thermal stability range of the fiber are indispensable. Physical characteristics like porosity, density and water absorption capacity have to be specified. In addition to these parameters, crystallinity rate and chemical composition of the fibre will be an undeniable asset.

The natural fibers characteristics depend on a number of factors like the age of the plant from which the fibers are extracted, the part of the plant where the fibers are located (leaf, fruit, stem) and the fibers extraction technique used [6]. The plant fibers most widely used as reinforcement for composite materials are flax, sisal, hemp, jute and kenaf [7]. This use is justified by their durability in the textile field, their availability and their specific properties. However, with the increase of demand in green materials combined to the decrease of growing space for these common plant fibers, and the race towards new tropical species which are accessible and at lower cost, some recent scientific works have been carried out in this field. Researches enabled to study new plant fibers such as those derived from pineapple leaves (PALF) [8], Rhectophyllum camerunense roots [1], Okra stems [9], Triumfetta cordifolia [10], Sida cordifolia [11], Arundo donax [7], Lygeum spartum [4], Coccinia grandis [12] for their use as reinforcement for composite materials.

The presented work investigates the properties of fibers extracted from the bast of Cola lepidota stem. They are characterized in order to choose the resin and the process for manufacturing a composite membrane reinforced by this tropical fiber. In South Cameroon, they are traditionally used to make hood ropes because of their resistance and workability.

In this article, the fiber extraction procedure was presented. The real density was assessed by using the helium pycnometry technique. Porosity was evaluated by density methods. Water content, organic and mineral matter content and water absorption capacity were calculated according to ASTM D1576-13, ASTM E1755-01 and ASTM D 5229 standards, respectively. Fourier Transform Infrared Spectroscopy with Attenuated Total Reflectance (FTIR-ATR) was used to determine chemical structure and crystallinity index of the fiber. Cellulose, hemicellulose, pectin, lignin and extractives contents were determined by using TAPPI test methods. Thermal behaviour was determined by thermogravimetric analysis (TGA) coupled with differential scanning calorimetry (DSC) using a STA 449F3 Jupiter from the German NETZSCH${ }^{\circledast}$ brand. 


\section{Materials and Methods}

\subsection{Raw Material}

The fibers studied in this work come from the bark of the stem of cola tree, genus Cola lepidota. They have been collected in the forest of Ebemewoman 2, a village located in the Southern part of Cameroon. This plant is mainly known by its fruit which contains white, sweet and edible arillus (Figure 1) called "monkey cola" or "ivoe" in its local language. It belongs to the Sterculiaceae family. It is an undergrowth shrub reaching $15 \mathrm{~m}$ in height and $25 \mathrm{~cm}$ in diameter; it has a humpy shaft and a slightly branched crown; its particularity is its bark: greyish-green to brown, its straight section shows a whitish slice with yellowish-brown lines and exuding a yellowish secretion [13]. This coloration is visible on the extracted raw fibers.

\subsection{Fibers Extraction}

Stagnant water retting procces was used to extract fibers. Figure 2 illustrates the differents steps of the CL fiber extraction procedure.

The fibers were collected on the main stem, specifically in central part in order to obtain optimal characteristics [6]. Stems with an average diameter of $10 \mathrm{~cm}$ were selected to perform the collection of bast.

The barks of CL (Figure 2(b)) were detached from the stem and exposed to the open air for two days for allowing binding agent of phloem to dry and facilitate the extraction process. Then, they were entirely submerged into a tank filled with water at ambient temperature for 4 weeks (Figure 2(c)) to undergo biological degradation. At the end of this period, the fiber bundles were loosed. They were then lightly hand whashed and rinsed several times with clean water to remove any external matter (Figure 2(d) and Figure 2(e)). The resulting product was spread out and dried in the room for one week (Figure 2(f)). We obtained bundles of yellowish-coloured fibers, soft and smooth to the touch with a grid texture (Figure $2(\mathrm{~g})$ ). The fiber bundles were combed to obtain a continuous ribbon; which is the CL fiber (Figure $2(\mathrm{~h})$ ).

\subsection{Characterization Methods}

\subsubsection{Densities and Porosities Measurements}

The real density was determined with the technique of helium pycnometry as described in [10]. The obtained value was verified by an evaluation of the density by the simple Rule of Mixture (ROM) by applying Equation (1).

$$
\rho_{\text {ROM }} \approx \frac{1}{\left(\frac{\% \text { cell }}{\rho_{\text {cell }}}+\frac{\% \text { hcell }}{\rho_{\text {hcell }}}+\frac{\% \text { lig }}{\rho_{\text {lig }}}+\frac{\% \text { pec }}{\rho_{\text {pec }}}\right)}
$$

where, \%cell, \%hcell, \%lig and \%pec stand for mass fractions of Cellulose, Hémicellulose, Lignin and Pectin respectively obtained by chemical composition of the fiber; $\rho_{\text {cell }}, \rho_{\text {hcell }}, \rho_{\text {lig }}$ and $\rho_{\text {pec }}$ used for densities of Cellulose, Hemicellulose, Lignin and Pectin respectively [14] [15]. 


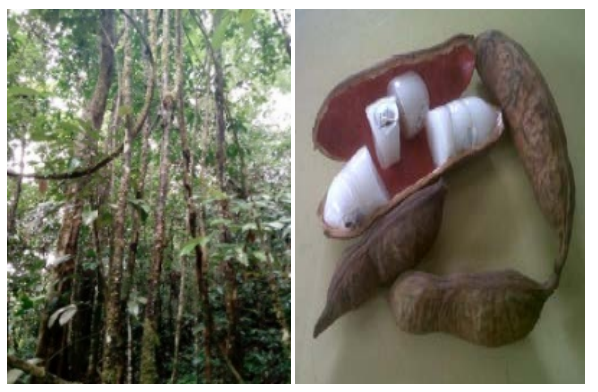

Figure 1. Cola lepidota: plants and fruits.

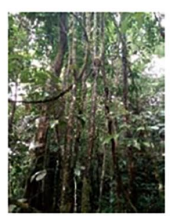

(a)

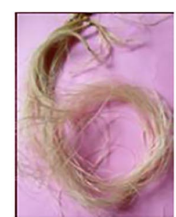

(h)

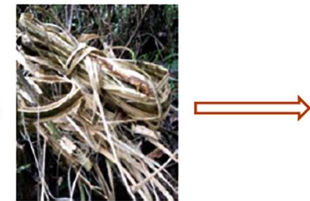

(b)

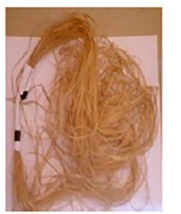

(g)

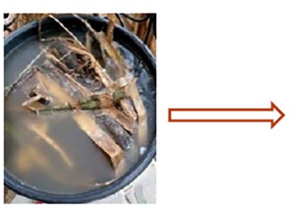

(c)

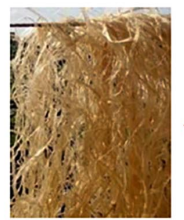

(f)

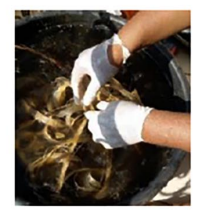

(d)
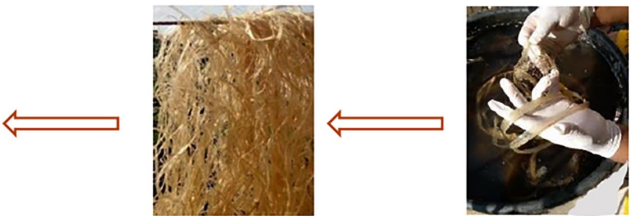

(e)

Figure 2. Extraction process of CL fibers. (a) CL plants selected, (b) CL bark, (c) Submerged CL bark, (d) Washing of CL bark after 4 weeks of soaking, (e) Rinsing of CL fibre bundle, (f) Dried CL fibre bundle (g), CL fiber bundles, (h) CL fiber.

Apparent (bulk) density was determined with the Archimedes method. It represents the mass of the fiber per unit of total volume including voids and inter-granular porosities. It is evaluated according to the ASTM D792 standard. After being dried for 48 hours in an oven at $65^{\circ} \mathrm{C}$ until the mass has stabilized, the fiber clumps were cooled in a desiccator and then weighed on a Sartorius $(1 / 10,000 \mathrm{~g})$ analytical balance. They were then coated with paraffin and reweighed before being immersed in a graduated test tube containing the solvent.

The porosity of fiber was evaluated by the density methods as described by Mwaikambo and Ansell [16] by applying Equation (2).

$$
P(\%)=\left(1-\frac{\rho_{a}}{\rho_{r}}\right) \times 100
$$

where, $\rho_{a}$ and $\rho_{r}$ represent the apparent and the real density of fiber in $\mathrm{g} / \mathrm{cm}^{3}$, respectively.

\subsubsection{Water Absorption}

The protocol described by Nadlene [17] was performed to determine the CL fibers water absorption. Previously dehydrated fibres were weighed $M_{0}(\mathrm{~g})$ and held in a desiccator containing fresh water for 24 hours. They were then removed and placed in the centrifuge set at $500 \mathrm{rpm}$ for 30 seconds to be drained before weighing $M_{1}(\mathrm{~g})$. Water absorption values were calculated by Equation (3). 


$$
W_{\mathrm{Abs}_{24}}(\%)=\frac{M_{1}-M_{0}}{M_{0}} \times 100
$$

\subsubsection{Moisture Content}

ASTM D1576-13 standard was used to evaluate the moisure content of CL fibers. Fiber samples previously exposed for 24 hours in a temperature controlled room of $27^{\circ} \mathrm{C} \pm 2^{\circ} \mathrm{C}$ with $65 \%$ relative humidity of air were weighed $M_{0}(\mathrm{~g})$. They were then dehydrated for 24 hours in a $105^{\circ} \mathrm{C}$ controlled oven and re-weighed $M_{1}(\mathrm{~g})$. The moisture content is defined by:

$$
W(\%)=\frac{M_{0}-M_{1}}{M_{1}} \times 100
$$

\subsubsection{Organic and Mineral Matter Contents}

The mineral content was determined by calcination according to ASTM E1755-01 standard. Fibers were ground and sieved. A mass of $1.5 \mathrm{~g}$ with a size of $315 \mu \mathrm{m}$ was dehydrated in an oven at $65^{\circ} \mathrm{C}$ for 48 hours and weighed $M_{1}(\mathrm{~g})$. They were then placed in an empty ceramic crucible weighed $M_{0}(\mathrm{~g})$ and then introduced into Naberther furnace set at $550^{\circ} \mathrm{C}$ for 4 hours. After this time, the assembly was cooled in a desiccator and weighed $M_{2}(\mathrm{~g})$. The mineral content was evaluated by the relation 5 .

$$
M_{\min }(\%)=\frac{M_{2}-M_{0}}{M_{1}-M_{0}} \times 100
$$

Organic content was deduced from Equation (5) by:

$$
M_{\text {org }}(\%)=100-M_{\text {min }}
$$

\subsubsection{Fourier Transform Infrared Spectroscopy in Attenuated Total Reflectance (FTIR-ATR) Spectrometry}

Fourier Transform Infrared Spectroscopy (FTIR) technique was carried out to determine the functional groups and chemical bonds present on the CL fiber. Infrared spectrum was recorded using a BRUKER ALPHA spectrometer operating in attenuated total reflectance (ATR) mode and controlled by Opus Lab v 7.0 122 software. Acquisitions were carried out by performing 200 scans in the frequency range 4000 and $400 \mathrm{~cm}^{-1}$, at spectral resolution of $4 \mathrm{~cm}^{-1}$. Fiber bundles were chopped, ground and dried. Then, a mass of $1 \mathrm{~g}$ was used for this purpose.

\subsubsection{Evaluation of Crystallinity Index by FTIR-ATR}

Crystallinity index (CrI) of the new fiber was evaluated by calculating the lateral order index (LOI) also called O'Connor crystallinity index from the FTIR-ATR spectrum of fiber [18] [19] [20]. In this work the ratio of the absorption band $I_{1422} / I_{898}$ seems to be more suitable for evaluating the CrI [20]. The LOI is computed by the relation 7 .

$$
\mathrm{LOI}=\frac{I_{1422}}{I_{898}}
$$

where, $I_{1422}$ and $I_{898}$ represent the intensity of the FTIR-ATR peaks at 1422 
$\mathrm{cm}^{-1}$ and $898 \mathrm{~cm}^{-1}$ absorption band respectively.

\subsubsection{Chemical Composition}

Chemical composition of CL fibers was carried out in accordance with (TAPPI) methods based on successive extraction of the components of the fibrous material by solvents as described by Sango [21]. This technique consits in isolating the different substances contained in the fiber. Ethanol-benzene extraction was first done. It was used to remove components such as dyes, wax, fats and lipids which are generally found in vegetable fibers. It was carried out with Soxhlet on previously dehydrated and crushed fibers. Then, hot water extraction was carried out to remove the residues of extractables still present in the sample obtained after extraction with ethanol-benzene and to solubilize all the mineral matter contained in the fiber. The pectin extraction was the third to be carried out. The residue from the previous extraction was heated in a water bath under reflux at $80^{\circ} \mathrm{C}$ while stirring with $2 \%$ of hydrochloric acid solution. Then, holocelullose (substance consisting of mixture of cellulose and hemicellulose) was extracted by total delignification of the sample obtained after extraction of the pectins by using $1 \%$ sodium hydroxide solution. The extraction of cellulose was the last step of the process: the previous holocellulose sample was dissolved in a $17.5 \%(\mathrm{w} / \mathrm{w}) \mathrm{NaOH}$ solution and then diluted in the same $8.75 \%(\mathrm{w} / \mathrm{w}) \mathrm{NaOH}$ solution. The solid residue obtained was successively washed with $1 \%$ acetic acid solution and distilled water. Hemicellulose content was deduced directly by subtracting cellulose content from that of holocellulose. A mass of $5 \mathrm{~g}$ of ground and dried fiber was used.

Lignin content was determined by the KLASON method [22]. A sample of $1 \mathrm{~g}$ of residue taken after pectins extraction was hydrolysed in $72 \%$ sulphuric acid solution, then heated under reflux in $3 \%$ sulphuric acid solution before being cooled and rinsed thoroughly with hot distilled water [21].

\subsubsection{Differential Scanning Calorimetry (DSC) and Thermogravimetric (TG) Analysis}

Thermogravimetric and differential scanning calorimetry analysis were used to evaluate the thermal stability and thermal decomposition of CL fibers. For this investigation, STA 449F3 Jupiter instrument of the German brand NETZSCH was used. A mass of $5 \mathrm{~g}$ of raw fiber powder with particle size of $200 \mu \mathrm{m}$ was heated from $36^{\circ} \mathrm{C}$ to $697^{\circ} \mathrm{C}$ at a heating rate of $10^{\circ} \mathrm{C} / \mathrm{min}$ in air atmosphere.

\section{Results and Discussions}

\subsection{Physical Properties}

\subsubsection{Water Absorption}

Water absorption capacity of raw CL fiber is $172 \%$. This content is closest from that of common natural fibers such as: alfa fibre $158 \%$ [23], flax $136 \% \pm 25 \%$, hemp $158 \% \pm 30 \%$, sisal $200 \%$, jute $281 \%$ and coconut $180 \%$ [24], which are generally used as reinforcement for composites. This relatively low rate could indicate a low porosity of the fiber and might contribute to good mechanical re- 
sistance [5]. This water absorption capacity also indicated the existence of free hydroxyl group, which attracts water molecules from the surrounding environment through hydrogen bonding [25]. These hydroxyl groups are responsible for the presence of hemicelluloses molecules in the fiber as shown in Figure 3. This content could inspire cautions that should be taken into account before the manufacturing of composites made from this fiber.

\subsubsection{Moisture Content}

The average moisture content of CL fibers is $6.47 \%$. This relatively low value content would predispose to good fiber-resin interaction in the manufacture of composite materials reinforced with the new lignocellulosic resource. A product made from this fiber would offer good comfort feeling because it will absorb less than $7 \%$ moisture content, very close to that of cotton and flax [23]. It is reported in litterature that high moisture content undermine the stability of the composite in terms of dimensions, tensile strength, swelling behaviour and porosity formation [17]. Therefore, lower moisture content is desirable.

\subsubsection{Organic and Mineral Matter Content}

The organic and mineral contents of CL fibers are $97.68 \%$ and $2.32 \%$ respectively. This ash content shows that the new fiber might have good fire resistance capacity [26].

\subsubsection{Densities and Porosities}

The real density of the CL fiber evaluated with the helium pycnometer is about $1.7266 \pm 0.0146 \mathrm{~g} / \mathrm{cm}^{3}$. This value is close to that of cotton $\left(1.6 \mathrm{~g} / \mathrm{cm}^{3}\right)$ [27]

Using the ROM law yields, we obtained $1.6368 \mathrm{~g} / \mathrm{cm}^{3}$, which correlates with the value obtained by the helium pycnometry technique.

The apparent density evaluated using the Archimedes thrust principle is about $1.205 \pm 0.2941 \mathrm{~g} / \mathrm{cm}^{3}$.

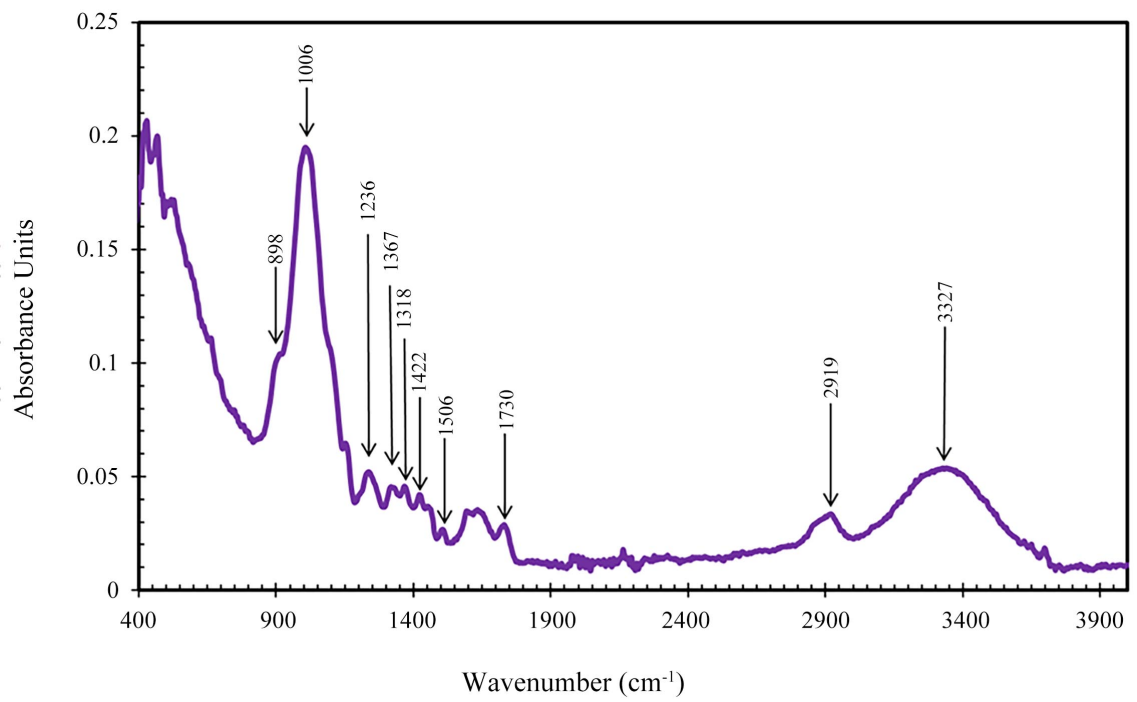

Figure 3. ATR-FTIR spectrum of CL fibers. 
Applying Equation (2), porosity fraction of CL fiber is between 13\% and 47\%. Although useful in applications where shock and vibration damping are required, and in resin impregnation during composite manufacturing, large porosities have detrimental impact on the mechanical properties of composite materials because they promote early failure of the parts due to the appearance areas of stress concentration and the reduction of effective cross-section [1] [5].

Table 1 shows porosities and densities of some common natural fibers used as reinforcement in composite materials.

\subsection{FTIR-ATR Analysis}

Figure 3 shows the FTIR-ATR spectrum of CL raw fiber and indicates the position of main absorption peaks while Table 2 presents functional groups and chemical bonds assigned to these mains points.

IR spectrum of CL shows similarities with that of well-known lignocellulosic materials [7] [10] [21]. Rekmarkable peaks are observed at wave numbers 3328, $2919,2163,1730,1236,1007,1422,1506,1367$ and $1236 \mathrm{~cm}^{-1}$ respectively.

Table 1. Some porosities and densities of common natural fibers.

\begin{tabular}{ccccc}
\hline Fibers types & Apparent density $\left(\mathrm{g} / \mathrm{cm}^{3}\right)$ & Real density $\left(\mathrm{g} / \mathrm{cm}^{3}\right)$ & Porosity $\%$ & References \\
\hline CL & $1.205 \pm 0.2941$ & $1.7266 \pm 0.0146$ & $13-47$ & Current study \\
Hemp & 1.468 & 1.505 & 2.46 & {$[16]$} \\
Coconut & $1.261-1.422$ & - & $38.01-50.87$ & {$[28]$} \\
Jute & 1.358 & 1.532 & 11.36 & {$[16]$} \\
Flax & 1.38 & 1.54 & 10 & {$[5]$} \\
RC & - & 0.947 & $28-35$ & {$[1]$} \\
Sisal & 1.273 & 1.428 & 10.85 & {$[16]$} \\
\hline
\end{tabular}

Table 2. Peak locations and respective functional groups for CL fiber.

\begin{tabular}{|c|c|c|}
\hline $\begin{array}{l}\text { Peak positions } \\
\left(\text { Wavenumber }\left(\mathrm{cm}^{-1}\right)\right)\end{array}$ & $\begin{array}{l}\text { Corresponding chemical } \\
\text { functional group }\end{array}$ & References \\
\hline 3328 & $\begin{array}{l}\mathrm{OH} \text { stretching vibration of polysaccharides and } \\
\text { water hydration }\end{array}$ & [9] [19] [29] \\
\hline 2919 & $\begin{array}{l}\mathrm{CH} \text { and } \mathrm{CH}_{2} \text { Stretching and vibrating of cellulose } \\
\text { and hemicellulose }\end{array}$ & {$[19][30]$} \\
\hline 1730 & $\begin{array}{l}\text { Ester or carboxylic acid }(\mathrm{C}=\mathrm{O}) \text { symetric stretching } \\
\text { vibration of Xylanes and/or lignin }\end{array}$ & {$[20][21]$} \\
\hline 1506 & $(\mathrm{C}=\mathrm{C})$ stretching and vibrating of lignin & {$[21][31]$} \\
\hline 1422 & $\mathrm{CH}_{2}$ symetric stretching and bending of cellulose & [7] [31] \\
\hline 1236 & Acetyl group (-COO) of hemicellulose & {$[4]$} \\
\hline 1007 & $(\mathrm{C}-\mathrm{OH})$ Vibration and deformation of lignin & {$[31]$} \\
\hline 898 & C-O group of monosaccharides & {$[4][20][31]$} \\
\hline
\end{tabular}


The peak at $3328 \mathrm{~cm}^{-1}$ is attributed to the presence of polysaccharides and hydration water [9] [19] [29]. The one observe at $2919 \mathrm{~cm}^{-1}$ is associated to the $\mathrm{C}-\mathrm{H}$ stretching vibration from $\mathrm{CH}$ and $\mathrm{CH}_{2}$ in cellulose and hemicellulose components [19] [30]. Absorption band centered at $1730 \mathrm{~cm}^{-1}$ corresponds to symetric stretching of ester or carboxylic acid groups $(\mathrm{C}=\mathrm{O})$ of xylans and/or lignin [20] [21]. The peak observed at $1506 \mathrm{~cm}^{-1}$ is attributed to carbon double bond $(\mathrm{C}=\mathrm{C})$ and the vibrations of polyphenolic groups responsible of lignin [21] [31]. The absorbance band at $1422 \mathrm{~cm}^{-1}$ is associated to $\mathrm{CH}_{2}$ symetric bending present in cellulose [7] [31]. Moreover, the two peaks presented at $1367 \mathrm{~cm}^{-1}$ and 1318 $\mathrm{cm}^{-1}$ are assigned respectively to bending vibration of $(\mathrm{C}-\mathrm{H})$ and $(\mathrm{C}-\mathrm{O})$ groups of aromatic ring in the polysaccharides while the absorption peak centered at $1236 \mathrm{~cm}^{-1}$ corresponds to (-COO) group of hemicellulose [4] [30]. The high absorbance at $1006 \mathrm{~cm}^{-1}$ is assigned to $(\mathrm{C}-\mathrm{OH})$ stretch of lignin [31]. Finally, the little peak at $898 \mathrm{~cm}^{-1}$ can be assigned to $\beta-1,4$ glycosidic linkage of (C-O) groups of cellulose [4] [20] [31].

Thus, the above analysis clairly proved that CL fibers are mainly composed of cellulose, hemicellulose, pectin, lignin and water.

\subsection{Crystallinity Index Analysis}

From IR spectrum analysis illustrated in Figure 3 and the description presented in [19] [32], it can be confirmed that cellulose I and II mixture, cellulose II and amorphous cellulose predominate in CL fiber.

The absorbance observed at $1422 \mathrm{~cm}^{-1}$ corresponds to the crystalline structure of cellulose II, while that at $898 \mathrm{~cm}^{-1}$ corresponds to its amorphous structure [29]. The Lateral Order Index (LOI) shows the order of crystallinity rather than the amount of crystalline cellulose relative to the amorphous components [33]. It is noted that in a sample composed mainly of cellulose II, LOI increases with a decreasing crystallinity of the fiber [32].

O'Connor's crystallinity index of the CL fiber is around $42 \%$. It is smaller than that of linden $96 \%$, althaea $79 \%$, ferula $70 \%$, conium maculatum $101 \%$ imperata brasiliensis $45.39 \%$ for which crystallinity index obtained by X-ray diffraction technique using Segal's empirical formula [4] [7] is $68 \%$ for althaea fibre, $53 \%$ for linden fibre, $55.7 \%$ for conium maculatum fibre and $36.6 \%$ for imperata brasiliensis fibre [19] [20].

\subsection{Chemical Composition}

Table 3 shows the result of chemical composition of CL fibers. The obtained values are compared to those previously reported in the literature for other lignocellulosic fibers used as a reinforcement for eco-composites structure.

CL fiber is mainly composed of cellulose, hemicellulose and lignin which occupied more than $80 \%$ of the constituent fractions. This result correlates with that shown in Figure 4 when thermal analysis of the fiber is performed. The cellulose content in CL fibre is closest to that of kenaf, jute, abaca fibres [2] [6] 
[7] and higher than that of fibres such as esparto, diss, banana or coconut [6] [21] [24], which are annual plants.

On the other hand, the lignin content obtained in the new fiber is similar to that of Rhectophyllum camerunense fiber [1] and unlike most fibres of the same nature. This value is relatively high and may be linked to the low moisture content found above [33].

Table 3. Chemical composition of CL and some common natural fibers.

\begin{tabular}{cccccccc}
\hline Fibers & $\begin{array}{c}\text { Cellulose } \\
\%\end{array}$ & $\begin{array}{c}\text { Hemicellulose } \\
\%\end{array}$ & $\begin{array}{c}\text { Lignin } \\
\%\end{array}$ & $\begin{array}{c}\text { Pectin } \\
\%\end{array}$ & $\begin{array}{c}\text { Extractives } \\
\%\end{array}$ & $\begin{array}{c}\text { Ash } \\
\%\end{array}$ & References \\
\hline${ }^{*}$ CL & 54.24 & 14.28 & 15.3 & 10.1 & 3.73 & 2.31 & Current study \\
Abaca & $56-63$ & $20-25$ & $7-13$ & 1 & 3 & - & {$[34]$} \\
Alfa & 48.29 & 35.84 & 7.8 & 1.05 & - & - & {$[35]$} \\
Banana & 37.5 & 28 & 14.7 & 6 & 13 & - & {$[21]$} \\
Hemp & $67-75$ & $16-18$ & $3-4$ & 0,8 & - & - & {$[6]$} \\
Coconut & $36-43$ & $0.15-14.7$ & $41-45$ & $3-4$ & - & - & {$[36]$} \\
Diss & 41.1 & 27 & 16.8 & 12.1 & - & - & {$[34]$} \\
Jute & $64-72$ & $12-13$ & $3-4$ & 0.2 & - & - & {$[6]$} \\
Kenaf & $45-57$ & 21.5 & $8-13$ & $3-5$ & - & - & {$[27]$} \\
Flax & $64-74$ & $10-20$ & 2 & 2 & - & - & {$[6]$} \\
$*$ RC & 68.2 & 16 & 15.6 & - & - & - & {$[1]$} \\
Sisal & $66-78$ & $10-14$ & $10-14$ & 10 & 2 & - & {$[27]$} \\
$*$ TC & 44.4 & 30.8 & 18.9 & 3.3 & 0.5 & 2.1 & {$[10]$} \\
\hline
\end{tabular}

${ }^{*} \mathrm{RC}$ : Rhectophyllum camerunense, ${ }^{\star} \mathrm{CL}$ : Cola lepidota ${ }^{*} \mathrm{TC}:$ Triumfetta cordifolia.

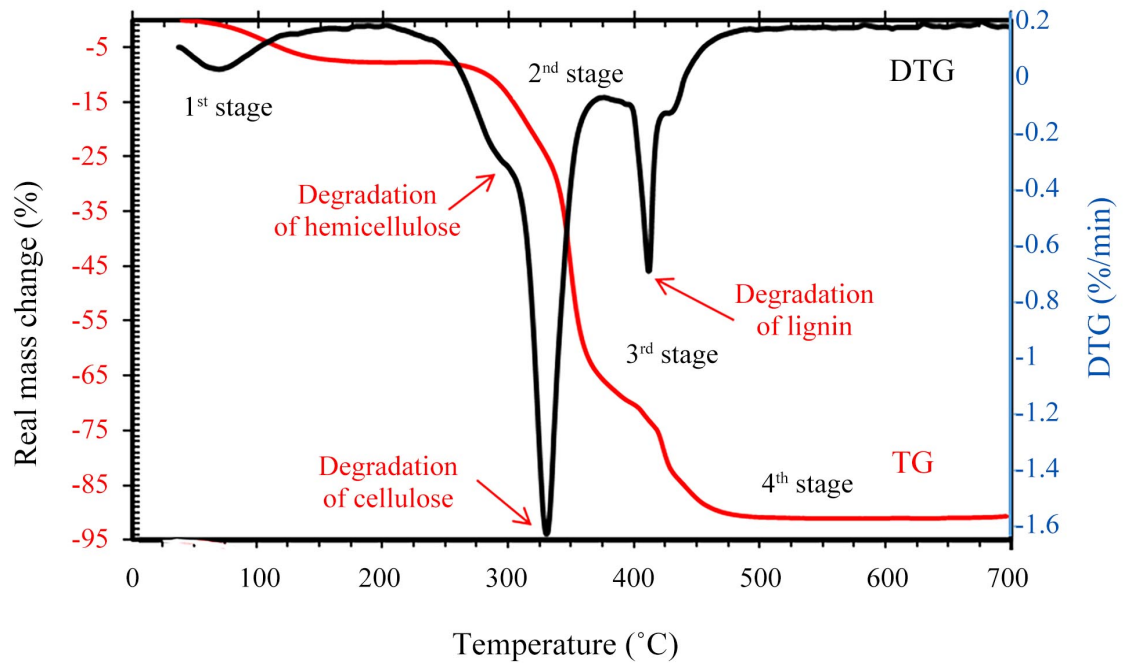

(a) 


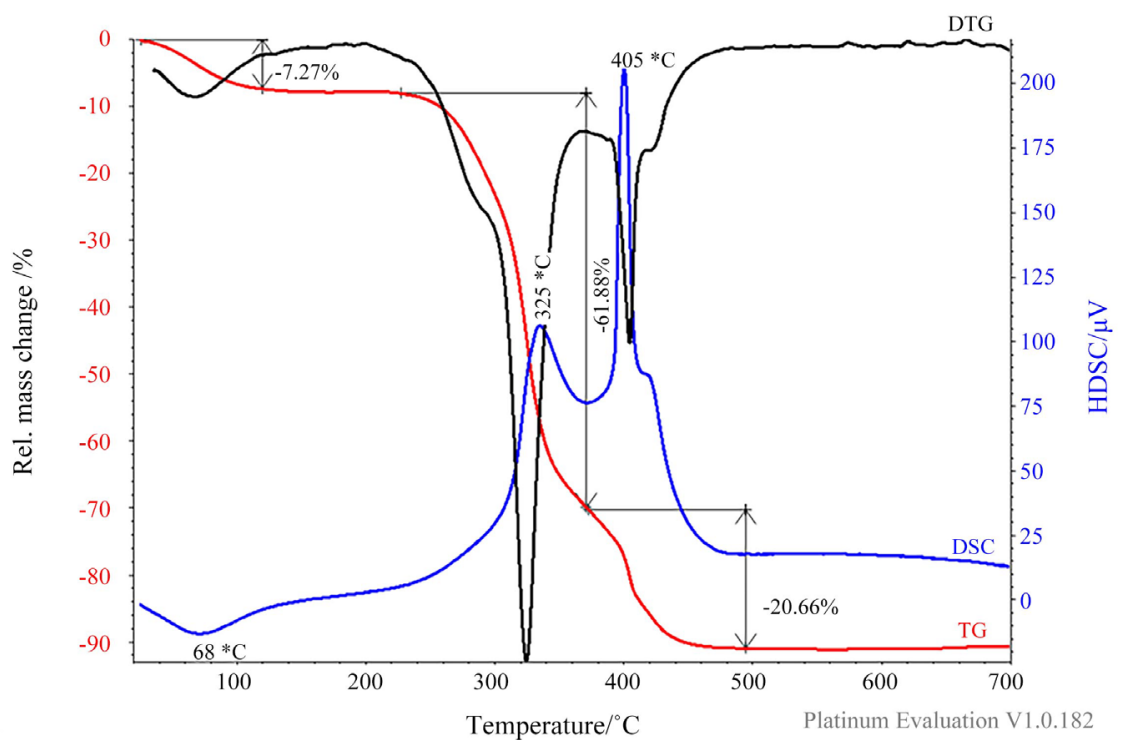

(b)

Figure 4. (a) TG and DTG curves of CL fiber; (b) TGA-DTG-DSC curves of the CL fiber.

\subsection{Thermal Analysis}

\subsubsection{Thermogravimetric Analysis}

Figure 4(a) shows combined thermogravimetric (TG) and its derivative thermographimetric (DTG) curves obtained at the thermal analysis of CL raw fiber.

TG curve clearly illustrates the decrease in weight with increasing temperature.This process is carried out in four stages.

The first stage occurs from $68^{\circ} \mathrm{C}$ up to $154^{\circ} \mathrm{C}$. It is characterised by a weight loss of $7.27 \%$ due to the dehydration of fiber [4] and evaporation of volatile substances such as alcohols, aldehydes, esters, organic acids, aliphatic hydrocarbons and the phenol groups present in the raw fiber [25]. Above $154^{\circ} \mathrm{C}$ up to $230^{\circ} \mathrm{C}$ a little loss in weight is observed. This range represents the thermal stability of the fiber. The second stage is between $230^{\circ} \mathrm{C}$ and $380^{\circ} \mathrm{C}$ with a loss weight of $69.15 \%$. At this stage, two main points are seen: the first between $280^{\circ} \mathrm{C}$ and $300^{\circ} \mathrm{C}$ a dip point is attributed to the decomposition of hemicelluloses, pectins and glycosidic bonds of cellulose [4]; the second, a peak, observed at $325^{\circ} \mathrm{C}$ corresponds to the maximum decomposition of the fiber. It is attributed to the degradation of cellulose I and celluloses present in the fiber [7]. The third stage is between $380^{\circ} \mathrm{C}$ and $490^{\circ} \mathrm{C}$. It is characterised by a weight loss of $20.66 \%$ attributed to the total decomposition of cellulose followed by that of the lignin and the other aromatic compounds of the fiber [21] [31]. It is reported that thermal decomposition of cellulose is from $350^{\circ} \mathrm{C}$ up to $375^{\circ} \mathrm{C}$ [17], while lignin, because of its complex structure, degrades slowly as the temperature rises in the sample. However, lignin is subject to significant degradation in the range $280^{\circ} \mathrm{C}-500^{\circ} \mathrm{C}$ [37]. The fourth stage takes place above $490^{\circ} \mathrm{C}$, the weight no longer varies and the fiber is completely calcined. The residual weight rate is $10.19 \%$.

A similar behaviour to that described above has already been reported by some works on other natural fibers [4] [7] [17] [21] [31]. 
Table 4 summarizes the thermal properties derived from TG-DTG whereas Table 5 contains the deduced chemical constituent of CL fiber obtained from TGA-DTGA results given in Figure 4. Table 6 presents the thermal properties of CL fibre in comparison with other common natural fibres used as reinforcement of composite materials.

\subsubsection{Differential Scanning Calorimetry Analysis}

Figure 4(b) shows combined TG-DTG-DSC curves of CL raw fiber while Table 7 summurizes its thermal properties obtained from DSC analysis. The DSC thermogram shows three main peaks: two exothermic straight peaks and one endothermic peak. The endothermic peak is observed at around $68^{\circ} \mathrm{C}$ and corresponds to dehumidification of the fiber [39]. The exothermic peaks are observed around $320^{\circ} \mathrm{C}$ and $340^{\circ} \mathrm{C}$ for the first and around $400^{\circ} \mathrm{C}$ and $410^{\circ} \mathrm{C}$ for the second. These peaks might successively be assigned to thermal degradation and decomposition temperatures of cellulose and lignin present in CL fiber [25] [40].

Table 4. Thermal properties from TG-DTG of CL fibre.

\begin{tabular}{cccccc}
\hline \multirow{2}{*}{ Sample } & \multicolumn{3}{c}{ Degradation temperature, ${ }^{\circ} \mathrm{C}$} & Thermal stability & Residual char, \\
\cline { 2 - 4 } & $\mathrm{T}_{\mathrm{IDT}}$ & $\mathrm{T}_{\mathrm{MDT}}$ & $\mathrm{T}_{\mathrm{FDT}}$ & & $\begin{array}{c}\text { range, }{ }^{\circ} \mathrm{C} \\
\text { CL fiber }\end{array}$ \\
\hline
\end{tabular}

*DT: Initial decomposition temperature, ${ }^{*}$ MDT: Maximum decomposition temperature, ${ }^{*}$ FDT: Final decomposition temperature.

Table 5. TG-DTG deduced chemical contents of CL fiber.

\begin{tabular}{ccccc}
\hline \multirow{2}{*}{ Sample } & \multicolumn{4}{c}{ Chemical compounds (\%) } \\
\cline { 2 - 5 } & Cellulose + Hemicellulose & Lignin & Ash & Volatiles \\
\hline \multirow{2}{*}{ CL fiber } & 61.88 & 20.66 & 10.19 & 7.27 \\
\hline
\end{tabular}

Table 6. Thermal properties of CL fibers and some others.

\begin{tabular}{ccccc}
\hline Fibers & $\begin{array}{c}\text { Initial } \\
\text { decomposition } \\
\text { temperature, }{ }^{\circ} \mathrm{C}\end{array}$ & $\begin{array}{c}\text { Maximum } \\
\text { decomposition } \\
\text { temperature }{ }^{\circ} \mathrm{C}\end{array}$ & $\begin{array}{c}\text { Residual } \\
\text { char, } \%\end{array}$ & Ref \\
\hline CL & 230 & 325 & $10.19\left(600^{\circ} \mathrm{C}\right)$ & $\begin{array}{c}\text { Current } \\
\text { study }\end{array}$ \\
$\begin{array}{c}\text { Prosopis juliflora bark } \\
\text { Banana }\end{array}$ & 217 & 331 & 8.21 & {$[38]$} \\
Lyguem spartum & 200 & 298 & 6 & {$[21]$} \\
Okra & 220 & 338.7 & $25.51\left(600^{\circ} \mathrm{C}\right)$ & {$[4]$} \\
Jute & 205 & 359 & 7.6 & {$[9]$} \\
Kenaf & 233.5 & 283 & 21 & {$[10]$} \\
TC & 235 & 442.2 & $10.49\left(900^{\circ} \mathrm{C}\right)$ & {$[10]$} \\
Hemp & 250 & 420 & $12.69\left(900^{\circ} \mathrm{C}\right)$ & {$[10]$} \\
Flax & 220 & 390 & - & {$[9]$} \\
\hline
\end{tabular}


Table 7. Thermal characteristics obtain from DSC analysis of raw CL fiber.

\begin{tabular}{ccccc}
\hline Fiber & \multicolumn{2}{c}{$\begin{array}{c}\text { Degradation temperature } \\
\text { of fiber components }{ }^{\circ} \mathrm{C}\end{array}$} & $\begin{array}{c}\text { Melt temperature } \\
\text { of fiber water, }{ }^{\circ} \mathrm{C}\end{array}$ & $\begin{array}{c}\text { Glass transition } \\
\text { temperature of the fiber, }{ }^{\circ} \mathrm{C}\end{array}$ \\
\cline { 2 - 5 } & $\mathrm{T}_{\mathrm{d}}$ cellulose & $\mathrm{T}_{\mathrm{d}}$ lignine & $\mathrm{T}_{\text {Onset }}$ & $\mathrm{T}_{\mathrm{g}}$ fibre \\
\hline $\mathrm{CL}$ & 335 & 405 & 108 & 246.66 \\
\hline
\end{tabular}

$T_{d}$ cellulose: degradation temperature of the cellulose of the fiber, $T_{d}$ lignin: degradation temperature of the lignin of the fiber, $\mathrm{T}_{\mathrm{g}}$ fiber: glass transition temperature of the fiber.

The melting temperature of water presents in the fibre $\left(\mathrm{T}_{\text {onset }}\right)$ is read from the graph by matching the extrapolated beginning of the curve by the intersection point of the tangent with the point of maximum slope on the principal side of the peak with the base line extrapolated [40]. On the same way, glass transition temperature $\left(\mathrm{T}_{\mathrm{g}}\right)$ is derived by a second order transition point. These methods allowed to find at around $108^{\circ} \mathrm{C}$ and $246^{\circ} \mathrm{C}$ respectively for $\mathrm{T}_{\text {onset }}$ and $\mathrm{T}_{\mathrm{g}}$.

It is worthy of note that CL fibers are stable until around $230^{\circ} \mathrm{C}$. This value is close than those of the average values of other common natural fibers as illustrated in Table 6. Thus, this new lignocellulosic fiber can be used with thermoset or thermoplastic polymer matrix under this temperature.

\section{Conclusions}

In this paper a new lignocellulosic fiber extracted from the bark of Cola lepidota stem is examined in order to evaluate the possibility of using them as eco-composite. Evaluation of water absorption capacity, moisture content, real density by helium pycnometer, porosity, chemical composition, chemical structure by FTIR-ATR, and thermal behaviour by TGA-DTG-DSC are some of the parameters investigated in this study. The salient results show that:

- CL fibers have a relatively low moisture content and its absorption capacity is similar to those of widely used common natural fibers such as flax, sisal, coconut, hemp and jute;

- The porosity of the fiber is between $13 \%$ and $47 \%$, which is appropriate for a good impregnation of low viscosity resin during the manufacture of an eco-composite;

- More than $80 \%$ of the fiber consists of cellulose, hemicellulose and lignin;

- The fiber is thermally stable up to $230^{\circ} \mathrm{C}$ with a maximum degradation temperature at around $325^{\circ} \mathrm{C}$; which is suitable for thermocompression molding with synthetic or natural polymeric resin;

- The result of chemical composition is consistent with that of the thermal behaviour study and correlates with those obtained at the evaluation of physical properties.

In perspective, a study is envisaged to implement a composite reinforced by this fiber and to characterize it.

\section{Acknowledgements}

Our thanks go to Jean-Bosco Saha Tchinda and Herman Assonfack Lekane of 
the Laboratory of Macromolecular Applied Chemistry Unit, Faculty of Sciences of the University of Yaounde 1, for their availability and practical advice.

\section{Conflicts of Interest}

The author declares no conflicts of interest regarding the publication of this paper.

\section{References}

[1] Béakou, A., Ntenga, R., Lepetit, J., Atéba, J.A. and Ayina, L.O. (2008) Physico-Chemical and Microstructural Characterization of "Rhectophyllum camerunense" Plant Fiber. Composites Part A: Applied Science and Manufacturing, 39, 67-74. https://doi.org/10.1016/j.compositesa.2007.09.002

[2] Malha, M. (2013) Mise en œuvre, caractérisation et modélisation de matériaux composite: Polymère thermoplastique renforcé par des fibres de Doum. Thèse de Doctorat, Université Mohammed V-Agdal, Rabat.

[3] Demaze, M.T. (2009) Le protocole de Kyoto, le clivage nord-sud et le défi du développement durable. Espace Geographique, Éditions Belin, Paris, 139-156. https://doi.org/10.3917/eg.382.0139

[4] Belouadah, Z., Ati, A. and Rokbi, M. (2015) Characterization of New Cellulosic Fiber from Lygeum spartum L. Carbohydrate Polymers, 134, 429-437. https://doi.org/10.1016/j.carbpol.2015.08.024

[5] Tossou, E. (2019) Développement de nouveaux composites hybrides renforcés par des fibres de carbone et de lin: Mise en oeuvre et Caractérisation mécanique. Thèse de Doctorat, Université de Caen Normandie, Caen.

[6] Charlet, K. (2006) Contribution à l'étude de composites unidirectionnels renforcés par des fibres de lin: Relation entre la microstructure de la fibre et ses propriétés mécaniques. Thèse de Doctorat, Université de Caen, Caen.

[7] Fiore, V., Scalici, T. and Valenza, A. (2014) Characterization of a New Natural Fiber from Arundo donax L. as Potential Reinforcement of Polymer Composites. Carbohydrate Polymers, 106, 77-83. https://doi.org/10.1016/j.carbpol.2014.02.016

[8] Jawaid, M., Asim, M., Tahir, P.M. and Nasir, M. (2020) Pineapple Leaf Fibers. Processing, Properties and Applications. Springer Nature Singapore Private Ltd., Singapore. https://doi.org/10.1007/978-981-15-1416-6

[9] De Rosa, I.M., Kenny, J.M., Puglia, D., Santulli, C. and Sarasini, F. (2010) Morphological, Thermal and Mechanical Characterization of Okra (Abelmoschus esculentus) Fibers as Potential Reinforcement in Polymer Composites. Composites Science and Technology, 70, 116-122. https://doi.org/10.1016/j.compscitech.2009.09.013

[10] Mewoli, A.E., Segovia, C, Betene Ebanda, F., Ateba, A., Noah, P.M.A., Ndiwe, B. and Njom, A. (2020) Physical-Chemical and Mechanical Characterization of the Bast Fibers of Triumfetta cordifolia A. Rich from the Equatorial Region of Cameroon. Journal of Minerals and Materials Characterization and Engineering, 8, 163-176. https://doi.org/10.4236/jmmce.2020.84011

[11] Manimaran, P., Prithiviraj, M., Saravanakumar, S.S., Arthanarieswaran, V.P. and Senthamaraikannan, P. (2017) Physicochemical, Tensile, and Thermal Characterization of New Natural Cellulosic Fibers from the Stems of Sida cordifolia. Journal of Natural Fibers, 15, 860-869. https://doi.org/10.1080/15440478.2017.1376301

[12] Jebadurai, S.G., Raj, R.E., Sreenivasan, V.S. and Binoj, J.S. (2018) Comprehensive Characterization of Natural Cellulosic Fiber from Coccinia grandis Stem. Carbohy- 
drate Polymers, 207, 675-683. https://doi.org/10.1016/j.carbpol.2018.12.027

[13] Eyog Matig, O., Ndoye, O., Kengue. J. and Awono, A. (2006) Les fruitiers forestiers comestibles du Cameroun. Rapport IPGRI, Rome.

[14] Youssefian, S. and Rahbar, N. (2015) Molecular Origin of Strength and Stiffness in Bamboo Fibrils. Scientific Reports, 5, Article No. 11116. https://doi.org/10.1038/srep11116

[15] Incropera, F., De Witt, D.P., Bergman, T.L. and Lavine, A.S. (2006) Fundamentals of Heat and Mass Transfer. 6th Edition, John Wiley \& Sons, Hoboken.

[16] Mwaikambo, L.Y. and Ansell, M.P. (2001) The Determination of Porosity and Cellulose Content of Plant Fibres by Density Methods. Journal of Materials Science Letters, 20, 2095-2096. https://doi.org/10.1023/A:1013703809964

[17] Nadlene, R., Sapuan, S.M., Jawaid, M., Ishak, M.R. and Yusriah, L. (2015) Material Characterization of Roselle Fiber (Hibiscus sabdariffa L.) as Potential Reinforcement Material for Polymer Composites. Fibers \& Textiles in Eastern Europe, 6, 23-30.

[18] Nelson, M.L. and O’Connor, R.T. (1964) Relation of Certain Infrared Bands to Cellulose Crystallinity and Crystal Lattice Type. Part I. Spectra of Lattice Types I, II, III and of Amorphous Cellulose. Journal of Applied Polymer Science, 8, 1311-1324. https://doi.org/10.1002/app.1964.070080322

[19] Kılınç A.Ç., Köktaş, S., Seki, Y., Atagür, M., Dalmis, R., Erdoğan, Ü.H., Göktaş A.A. and Seydibeyoğlu, M. (2018) Extraction and Investigation of Lightweight and Porous Natural Fiber from Conium maculatum as a Potential Reinforcement for Composite Materials in Transportation. Composites Part B: Engineering, 140, 1-8. https://doi.org/10.1016/j.compositesb.2017.11.059

[20] De Carvalho Benini, K.C.C., Voorwald, H.J.C., Cioffi, M.O.H., Milanese, A.C., Heitor, L. and Ornaghi, J.R. (2016) Characterization of a New Lignocellulosic Fiber from Brazil: Imperata brasiliensis (Brazilian Satintail) as an Alternative Source for Nanocellulose Extraction. Journal of Natural Fibers, 14, 112-125. https://doi.org/10.1080/15440478.2016.1167647

[21] Sango, T., Yona, A.M.C., Duchatel, L., Marin, A., Ndikontar, M.K., Joly, N. and Lefebvre, J.M. (2018) Step-Wise Multi-Scale Deconstruction of Banana Pseudo-Stem (Musa acuminata) Biomass and Morpho-Mechanical Characterization of Extracted Long Fibres for Sustainable Applications. Industrial Crops and Products, 122, 657-668. https://doi.org/10.1016/j.indcrop.2018.06.050

[22] Pearl, I.A. (1967) The Chemistry of Lignin. Marcell Dekker, New York, 339.

[23] Dallel, M. (2012) Evaluation du potentiel textile des fibres d'Alfa (Stipa tenacissima L.) caractérisation Physico-Chimique de lafibre au fil. Thèse de Doctorat, Université de Haute Alsace, Mulhouse.

[24] Page, J. (2017) Formulation et caractérisation d'un composite cimentaire bio-fibré pour des procédés de construction préfabriquée. Thèse de Doctorat, Université de Normandie, Normandie.

[25] Gonçalvesa, A.P.B., De Mirandaa, C.S., Guimarãesa, D.H., Oliveiraa, J.C., Cruza, A.M.F., Da Silvaa, F.L.B.M., Luporinia, S. and Joséa, N.M. (2015) Physicochemical, Mechanical and Morphologic Characterization of Purple Banana Fibers. Materials Research, 18, 205-209. https://doi.org/10.1590/1516-1439.366414

[26] Chapple, S. and Anandjiwala, R. (2010) Flammability of Natural Fiber-Reinforced Composites and Strategies for Fire Retardancy: A Review. Journal of Thermoplastic Composite Materials, 23, 871-893. https://doi.org/10.1177/0892705709356338

[27] Akil, H.M., Omar, M.F., Mazuki, A.A.M., Safiee, S., Ishak, Z.A.M. and Abu Bakar, 
A. (2011) Kenaf Fiber Reinforced Composites: A Review. Materials \& Design, 32, 4107-4121. https://doi.org/10.1016/j.matdes.2011.04.008

[28] Da Luz, F.S. and Monteiro, S.N. (2017) Analysis of Coir Fiber Porosity. Springer International Publishing, Berlin.

[29] Sbiai, A. (2011) Matériaux composite à matrice époxyde chargée par des fibres de palmier dattier: Effet de l'oxydation au tempo sur les fibres. Thèse de Doctorat, Université INSA-Lyon.

[30] Wang, H., Memon, H., Hassan, E.A.M., Miah, M.S. and Ali, M.A. (2019) Effect of Jute Fiber Modification on Mechanical Properties of Jute Fiber Composite. Materials, 12, 1226. https://doi.org/10.3390/ma12081226

[31] Fiore, V., Scalici, T. and Valenza, A. (2011) Artichoke (Cynara cardunculus L.) Fibres as Potential Reinforcement of Composite Structures. Composites Science and Technology, 71, 1138-1144. https://doi.org/10.1016/j.compscitech.2011.04.003

[32] Carrillo, F., Colom, X., Sunol, J.J. and Saurina, J. (2004) Structural FTIR Analysis and Thermal Characterisation of Lyocell and Viscose-Type Fibres. European Polymer Journal, 40, 2229-2234. https://doi.org/10.1016/j.eurpolymj.2004.05.003

[33] Seki, Y., Seki, Y., Sarıkanat, M., Sever, K., Durmuşkahya, C. and Ebru, B. (2014) Evaluation of Linden Fibre as a Potential Reinforcement Material for Polymer Composites. Journal of Industrial Textiles, 45, 1221-1238. https://doi.org/10.1177/1528083714557055

[34] Marta, F.V., Elias, B., Christoph, B., Alexander, B. and Koon-Yang, L. (2017) Plant Fibre-Reinforced Polymers: Where Do We Stand in Terms of Tensile Properties? International Materials Rewies.

[35] El-Abbassi, F.E., Assarar, M., Ayad, R., Bourmaud, A. and Baley, C. (2020) A Review on Alfa Fibre (Stipa tenacissima L.): From the Plant Architecture to the Reinforcement of Polymer Composites. Composites Part A: Applied Science and Manufacturing, 128, Article ID: 105677. https://doi.org/10.1016/j.compositesa.2019.105677

[36] Gurunathan, T., Mohanty, S. and Nayak, S.K. (2015) A Review of the Recent Developmentsin Biocomposites Based on Natural Fibres and Their Application Perspectives. Composites Part A: Applied Science and Manufacturing, 77, 1-25. https://doi.org/10.1016/j.compositesa.2015.06.007

[37] Singh, K., Risse, M., Das, K.C. and Worley, J. (2009) Determination of Composition of Cellulose and Lignin Mixtures Using Thermogravimetric Analysis. Journal of Energy Resources Technology, 131, 219-226. https://doi.org/10.1115/1.3120349

[38] Saravanakumar, S.S., Kumaravel, A., Nagarajan, T., Sudhakar, P. and Baskaran, R. (2013) Characterization of a Novel Natural Cellulosic Fiber from Prosopis juliflora Bark. Carbohydrate Polymers, 92, 1928-1933. https://doi.org/10.1016/j.carbpol.2012.11.064

[39] Ganapathy, T., Sathiskumar, R., Senthamaraikannan, P., Saravanakumar, S.S. and Khan, A. (2019) Characterization of Raw and Alkali Treated New Natural Cellulosic Fibres Extracted from the Aerial Roots of Banyan Tree. International Journal of Biological Macromolecules, 138, 573-581. https://doi.org/10.1016/j.ijbiomac.2019.07.136

[40] Ntenga, R., Mfoumou, E., Béakou, A., Tango, M., Kamga, J. and Ahmed, A. (2018) Insight on the Ultrastructure, Physicochemical, Thermal Characteristics and Applications of Palm Kernel Shells. Materials Sciences and Applications, 9, 790-811. https://doi.org/10.4236/msa.2018.910057 